\title{
FAOSTAT estimates of greenhouse gas emissions from biomass and peat fires
}

\author{
Simone Rossi ${ }^{1,2} \cdot$ Francesco N. Tubiello $^{1} \cdot$ Paolo Prosperi $^{1} \cdot$ \\ Mirella Salvatore $^{1} \cdot$ Heather Jacobs $^{1} \cdot$ Riccardo Biancalani $^{1}$. \\ Joanna I. House ${ }^{3} \cdot$ Luigi Boschetti $^{4}$
}

Received: 3 February 2015 / Accepted: 13 December 2015 /Published online: 5 January 2016

(C) The Author(s) 2015. This article is published with open access at Springerlink.com

\begin{abstract}
The Global Fire Emissions Database (GFED3) and the FAOSTAT Emissions database, containing estimates of greenhouse gas (GHG) emissions from biomass burning and peat fires, are compared. The two datasets formed the basis for several analyses in the fifth Assessment Report of the Intergovernmental Panel on Climate Change (IPCC AR5), and thus represent a critical source of information for emissions inventories at national, regional and global level. The two databases differ in their level of computational complexity in estimating emissions. While both use the same burned area information from remote sensing, estimates of available biomass are computed in GFED3 at tier 3 using a complex dynamic vegetation model, while they are computed in FAOSTAT using default, tier 1 parameters from the Intergovernmental Panel on Climate Change (IPCC). Over the analysis period 1997-2011, the two methods were found to produce very similar global GHG emissions estimates for each of the five GFED aggregated biomass fire classes: i) Savanna; ii) Woodland; iii) Forest; iv) Deforestation; v) Peatlands; with total emissions ranging 6-8 Gt CO2eq $\mathrm{yr}^{-1}$. The main differences between the two datasets were found with respect to peat fires, with FAOSTAT showing a lower 1997-1998 peak in emissions compared with GFED3, within an otherwise good agreement for the rest of the study period, when limited to the three tropical countries covered by GFED. Conversely, FAOSTAT global emissions from peat fires, including both boreal and tropical regions, were several times larger than those currently estimated by GFED3. Results
\end{abstract}

Francesco N. Tubiello

francesco.tubiello@fao.org

1 Food and Agriculture Organization of the United Nations, viale delle Terme di Caracalla, 00153 Rome, Italy

2 Present address: Institute for Environment and Sustainability, The European Commission Joint Research Centre, Ispra, VA, Italy

3 School of Geographical Sciences, University of Bristol, University Road, Bristol, UK

4 Department of Forest, Rangeland and Fire Sciences, College of Natural Resources, University of Idaho, Moscow, ID, USA 
show that FAOSTAT activity data and emission estimates for biomass fires offer a robust alternative to the more sophisticated GFED data, representing a valuable resource for national GHG inventory experts, especially in countries where technical and institutional constraints may limit access, generation and maintenance of more complex methodologies and data.

\section{Introduction}

Biomass fires emit greenhouse gases (GHGs) in the atmosphere, where they affect the interannual variability and growth rate of $\mathrm{CO}_{2}, \mathrm{CH}_{4}$ and $\mathrm{N}_{2} \mathrm{O}$ and other trace gases (Smith et al. 2014). Anthropogenic emissions of non- $\mathrm{CO}_{2}$ gases from peat and forest fires were 300 million $\mathrm{tCO}_{2}$ eq $\mathrm{yr}^{-1}$ on average over the period 2001-2010 (Smith et al. 2014), with prescribed burning of savanna adding 200 million $\mathrm{tCO}_{2}$ eq $\mathrm{yr}^{-1}$ (Tubiello et al. 2014). Slash and burn practices associated with deforestation were furthermore responsible for over 1.5 billion $\mathrm{tCO}_{2}$ eq $\mathrm{yr}^{-1}$ as direct $\mathrm{CO}_{2}$ gas (van der Werf et al. 2010).

Specific fire emission categories are significant in terms of their overall regional impacts. For instance, in Africa, prescribed burning of savanna represents $25 \%$ of total agricultural emissions (Tubiello et al. 2014). In South-east Asia, fires in drained tropical peatland, often linked to palm oil cultivation, can lead to significant emissions in specific years, with impacts seen at large regional and even global scales (Hayasaka et al. 2014).

Fire emissions linked to human-induced land-use and land use change activities, such as prescribed burning of savanna, deforestation and peatland degradation, need to be reported by countries to the UN Framework Convention on Climate Change (UNFCCC) (Stocker et al. 2013). Reporting obligations include compilation and submission of national GHG inventories within both National Communications and Biennial Update Reports. The Guidelines for National Greenhouse Gas Inventories, developed by the Intergovernmental Panel on Climate Change (IPCC 2006) allow countries to estimate and report data at various tiers of complexity, from simpler (Tier 1) to more complex (Tiers 2 and 3) approaches.

The simplest Tier 1 approach consists in the multiplication of burned area by default, static parameters describing the biomass available for combustion per hectare, and by GHG emission factors, differentiated by broad geographical, climatic or vegetation characteristics. Tier 2 approaches use the same method, but employ country specific, rather than default parameters. Tier 3 approaches allow for the use of more complex models to derive the necessary parameters, including simulation of biophysical variables at fine temporal and geospatial scales.

Most published estimation methods for quantifying GHG emissions from biomass fires are Tier 3 approaches (e.g., Stroppiana et al. 2010). Experts in developing countries however, including those tasked with implementing national GHG inventories, often face technical and institutional constraints that may limit access, generation and maintenance of data using the complex estimation methods linked to these higher tiers. Understanding differences in and availability of emission data estimated at differing levels of complexity is therefore important in order to plan and implement sustainable national GHG inventory systems.

To this end, we compared data from two available methodologies from the recent IPCC AR5 Report: the Global Fire Emissions Database version 3.1 (GFED3) (Van der Werf et al. 2010), used in WGI chapter 6 on the carbon cycle (Ciais et al. 2013); and the FAOSTAT Emissions database (Tubiello et al. 2013), used in WGIII chapter 11 on Agriculture, Forestry, and Other Land Uses (AFOLU) (Smith et al. 2014).

While both databases rely on remote-sensing information on burned area by land cover class, GFED3 is a Tier 3 approach, employing a dynamic vegetation model to determine fuel 
biomass consumption values at fine temporal and spatial scales. By contrast, FAOSTAT applies a Tier 1 approach using default vegetation parameters from the 2006 IPCC Guidelines (Tubiello et al. 2014). The aim of this work is to conduct a first robust assessment of differences and similarities between the two databases. While the results of such a comparison are of general scientific interest, given the above-discussed importance of biomass fires emissions at global and regional scales, they also provide specific, valuable information to national GHG inventory compilers, especially in developing countries, towards assessing the costs and the benefits of moving from simple approaches, of easy applicability and sustainability, to more sophisticated modelling tools requiring complex data processing and management.

\section{Materials and methods}

The 2006 IPCC Guidelines present a generic equation for the estimation of biomass and peat fires emissions, based on the bottom-up approach first proposed by Seiler and Crutzen (1980):

$$
L_{f i r e, x, v}=A_{v} * M_{B, v} * C_{f, v} * G_{e f, x, v}
$$

where:

- $\quad L_{\text {fire }, x, v}$ are GHG emissions of gas $\mathrm{x}$, for a given vegetation type $v$, at a given time;

- $A_{v}$ is the burned area with vegetation cover $v$;

- $M_{B, v}$ is the biomass fuel available for combustion of vegetation type $v$, including biomass, dead wood, and ground litter;

- $C_{f, v}$ is a combustion factor, indicating the efficiency of combustion of vegetation type $v$; and

- $G_{e f, x, v}$ is the emission factor for gas $\mathrm{x}$ and for the vegetation type $v$.

Altogether, $M_{B, v}$ and $C_{f, v}$ are referred to as fuel biomass consumption values. They can be derived either from field data or via models, while emission factors are derived from experimental data. The following sub-sections specify the input data used in Eq. (1) by the two methods considered herein.

\subsection{Burned area and land cover classes}

Both GFED3 and FAOSTAT employ the GFED Burned Area dataset version 3.1 (GFED3-BA) (Giglio et al. 2010) as input for burned areas in Eq. (1) above. GFED3-BA is largely based on the Moderate Resolution Imaging Spectroradiometer (MODIS) Direct Broadcast Burned Area Monthly L3 Global $500 \mathrm{~m}$ product (MCD64A1) (Giglio et al. 2009), with time coverage extended to the pre-MODIS era back to June 1996, by harmonizing MODIS data with those from other sensors, namely the Tropical Rainfall Measuring Mission (TRMM) Visible and Infrared Scanner (VIRS) and the Along-Track Scanning Radiometer (ATSR) family of sensors. The GFED Burned Area Datasets provide the longest consistent global time series of observed burned area data available in the literature. The GFED3-BA covers the period June 1997March 2012, with monthly maps at 0.5-degree spatial resolution; the more recent GFED4-BA (Giglio et al. 2013) covers the period June 1995-March 2014, with a 0.25-degree spatial resolution and daily/monthly temporal resolution. Each data value represents the total area 
burned in a given cell over 1 month. An additional data layer contains the share of the total burned area by land cover class, following the University of Maryland (UMD) classification system (Hansen et al. 2000), identified through the MODIS Land Cover Type Yearly L3 Global $500 \mathrm{~m}$ product (MCD12Q1) (Friedl et al. 2010). The UMD classification contains the following six land cover classes: i) Savanna; ii) Woody savanna; iii) Open shrublands; iv) Closed shrublands; v) Grassland; vi) Forests. Yearly burned area maps are produced in FAOSTAT by extracting monthly GFED-BA data and then aggregating in yearly composites for each UMD land cover class.

Emissions from peatland fires are also computed in both GFED3 and FAOSTAT, in an attempt to quantify the additional burning of the peat soil component underlying a given burned area and land cover type. The association of a given burned area to peat fire is made independently from the MODIS MCD12Q1 land cover information, as peat soil is not a land cover type. To this end, GFED3 uses a map of ecosystem types (Olson et al. 2001), as a proxy to associate burned areas to peat fires, but limited to Brunei, Indonesia and Malaysia. FAOSTAT applies instead the Harmonized World Soil Database (HWSD) (FAO/IIASA/ISRIC/ISSCAS/JRC 2012), a robust proxy for characterizing peat soils globally (IPCC 2006).

\subsection{Fuel biomass consumption values}

Estimates of fuel biomass consumption values represented the main difference between GFED and FAOSTAT. GFED employs a revised version of the Carnegie-Ames-Stanford-Approach (CASA) dynamic vegetation growth model (Potter et al. 1993) to estimate available biomass amounts as a function of climate and soil parameters, at each pixel and over time for the period of interest. Fuel biomass consumption values and their associated GHG emissions are estimated in monthly intervals and were then aggregated to yearly values. By contrast, FAOSTAT utilizes IPCC default annual fuel biomass consumption values from IPCC (2006), differentiated by different vegetation, soil and climate types (see Table 1), but constant over time (Tubiello et al. 2014). Peatland coefficients were taken from the IPCC Wetlands Supplement (IPCC 2013).

In order to match the IPCC classes with the UMD land cover classes used by GFED3-BA, and thus assign appropriate IPCC fuel biomass consumption values to each pixel, we determined the agro-ecological zones and ecosystem types associated to specific IPCC fuel biomass consumption values, based on IPCC references, and then assigned these values using geo-referenced maps. Specifically, IPCC fuel biomass consumption values for forest subcategories (i.e., boreal, temperate, tropical forest) were assigned to burned forest area pixels by using the FAO Global Ecological Zones map (FAO 2012). For pixels characterized by other vegetation types (e.g., savanna, woody savanna, grassland), tropical and non-tropical IPCC parameter values were assigned using the JRC-IPCC Climate Zones map (JRC 2010).

\subsection{Emission factors}

GFED3 and FAOSTAT use very similar GHG emissions factors for Eq. (1). The GFED3 values, derived from Andreae and Merlet (2001) and Christian et al. (2003), are consistent with the default IPCC 2006 values used by FAOSTAT. For peatlands, for which no 2006 IPCC emission factors exist, FAOSTAT applied those used by GFED3 (Table 1). 


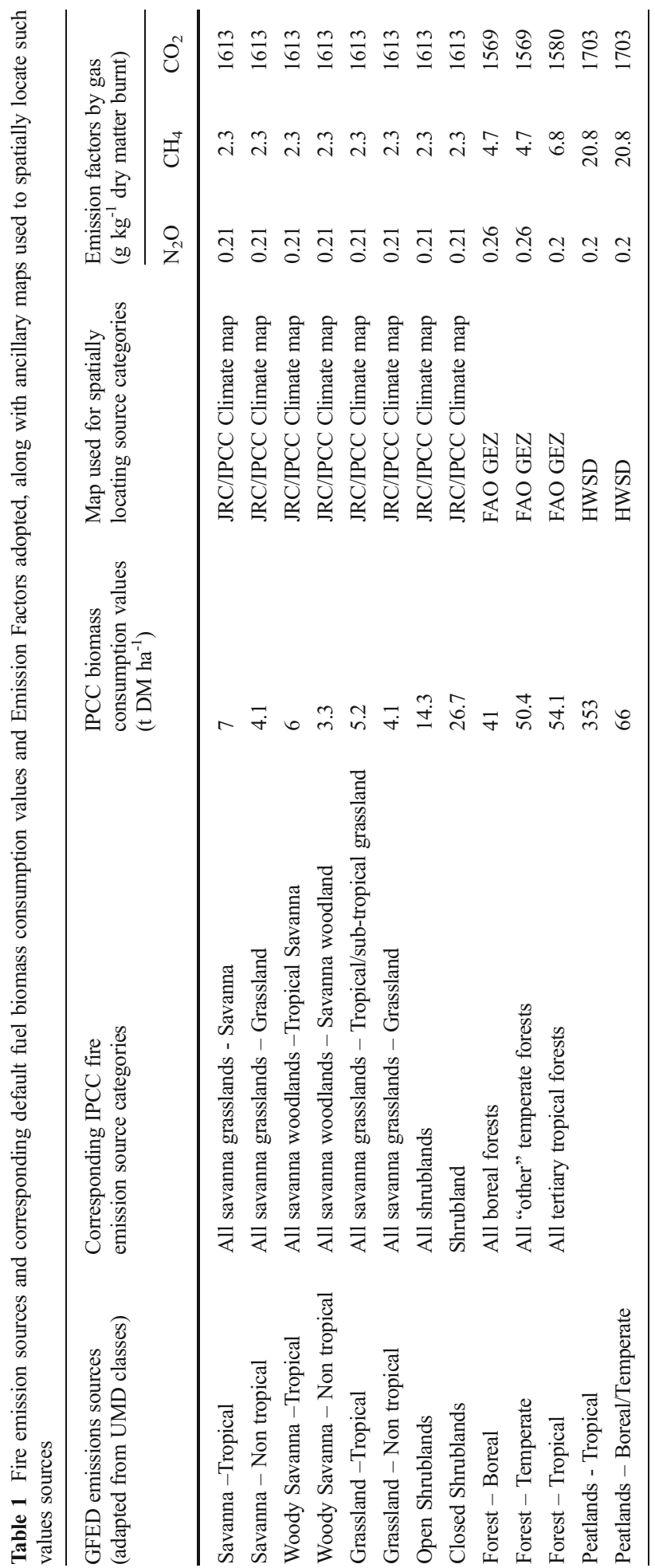




\subsection{GHG emissions}

GFED3 emissions are computed by classifying fires into six land cover classes: i) Deforestation; ii) Forest; iii) Woodland; iv) Savanna and Grassland; v) Peatland; and vi) Agriculture. While the underlying, GFED-BA burned area data follow the six land cover UMD classes, as discussed, the GFED emissions data are partitioned using UMD classes and ancillary datasets, such as the MOD44 MODIS continuous vegetation field product and the already mentioned ecosystems map. By contrast, FAOSTAT emissions classes are solely based on the UMD land cover classification, and aggregated in line with IPCC guidelines and UNFCCC reporting requirements. FAOSTAT emissions thus include the following six classes: i) Humid Tropical Forest; ii) Other Forest; iii) All Savanna (subdivided in savanna, woody savanna, closed and open shrublands, and grasslands); iv) Peatland; and v) Agriculture.

For the purpose of this work, it was necessary to re-aggregate FAOSTAT emission classes into those used by GFED. The re-aggregation performed was rather straightforward (Table 2) and allowed for direct comparison between the two emissions datasets. The overall mapping of UMD-based FAOSTAT into the GFED emission classes deforestation and peat fires nonetheless required application of common sense and expert judgement, corroborated by repeated testing. This is because in GFED, fire emissions are associated to deforestation and peat fires based on more than land cover classification. Specifically, in GFED the deforestation fire emission class is determined by using additional MODIS fire products, and the peat fires emission class is determined by using additional information on soil water status, obtained via complex hydrological modelling. In the end, FAOSTAT emission estimates from fire in humid tropical forests were used to compare to the GFED deforestation class, and FAOSTAT emissions estimates from peatlands were used to compare to the GFED peat fires class.

The comparison between GFED and FAOSTAT emissions data was limited to $\mathrm{CH}_{4}, \mathrm{~N}_{2} \mathrm{O}$ and $\mathrm{CO}_{2}$ gases, as these are those included in national GHG inventories. We did not compare emissions for the agricultural fires class, since FAOSTAT does not use GFED-BA products to estimate them, but rather the simpler IPCC Tier 1 approach, based on total harvested area by crop from national statistics. Comparisons over the remaining five classes were furthermore performed using $\mathrm{CO}_{2} \mathrm{eq}$ units rather than considering the three single gases $\mathrm{CO}_{2}, \mathrm{CH}_{4}$ and $\mathrm{N}_{2} \mathrm{O}$, since trends in each component gas are fully correlated to their equivalent total. This is because the emission factor for each gas is a constant multiplied by the same underlying biomass combustion value. Finally, a downscaling factor of 10 was applied to all GFED3 burned area data, in order to reconcile data from the GFED online database with those published in van der Werf et al. (2010) (L. Giglio, personal communication).

The reader is advised that while we discuss herein results based on the GFED3-BA products in order to maintain coherence with published GFED emissions data and with the data used in the IPCC AR5, the FAOSTAT GHG emission estimates currently distributed by FAO (Tubiello et al. 2015) are already based on the new GFED4-BA dataset (Giglio et al. 2013).

\section{Results and discussion}

Yearly GHG emissions from biomass burning produced by GFED3 and FAOSTAT were compared over the period 1997-2011, at both global scale and grid cell level. This paper reports mainly on the results of the comparisons performed at global scale, with some additional information on the grid cell level analysis. 


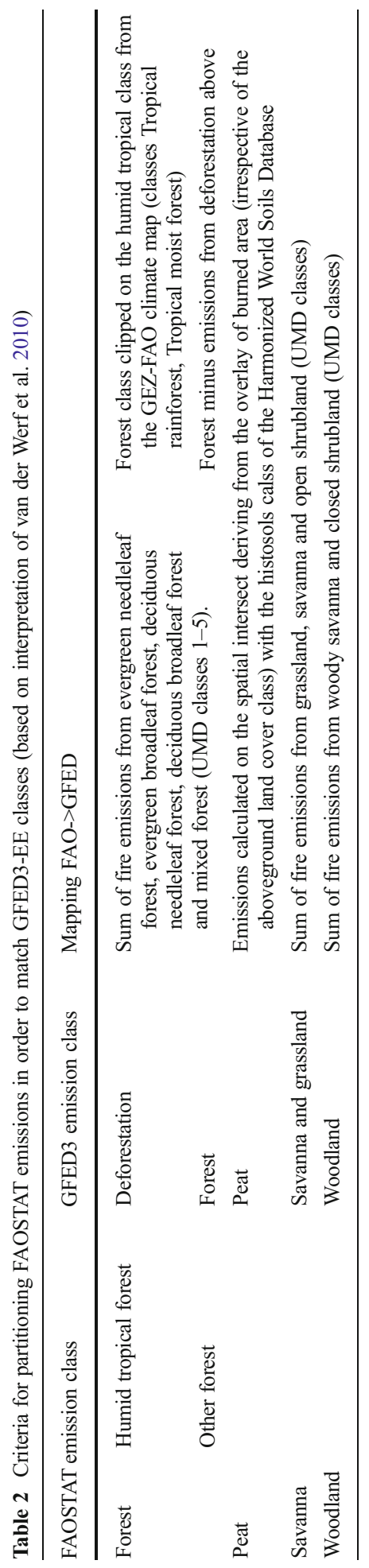


The overall GHG estimates were found to be similar between approaches, i.e., not statistically different for all the classes considered (Table 3, Fig. 1).

GFED3 and FAOSTAT estimates indicate global total emissions over the study period at $7.18 \pm 1.37 \mathrm{Pg} \mathrm{CO}_{2} \mathrm{eq} \mathrm{yr}^{-1}$ and $6.92 \pm 0.77 \mathrm{Pg} \mathrm{CO}_{2} \mathrm{eq} \mathrm{yr}^{-1}$, respectively, with moderate positive correlation, i.e., with a Pearson's correlation coefficient $\rho=0.53(p<.05)$ (Table 3, Fig. 1). The larger variability of GFED versus FAOSTAT data observed at the global level, i.e., coefficient of variation $(\mathrm{CV})=19 \%$ vs. $\mathrm{CV}=11 \%$, respectively, reflects the use of the CASA model by GFED to derive variable biomass combustion values, as opposed to the static default IPCC values used by FAOSTAT. Further investigation confirmed this feature for the other land cover classes,

The overall good agreement over the study period 1997-2011 between global GFED and FAOSTAT total emission estimates was also evident maintained for single fire emission classes (Table 3, Fig. 2). For deforestation, global GHG estimates with GFED and FAOSTAT were

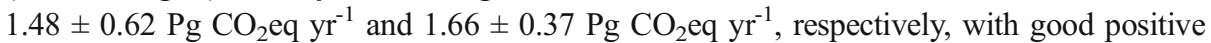
correlation, i.e. $\rho=0.71(p<.05)$. For forest, estimates were $1.02 \pm 0.35 \mathrm{Pg} \mathrm{CO}_{2} \mathrm{eq} \mathrm{yr}^{-1}$ and $1.01 \pm 0.17 \mathrm{Pg} \mathrm{CO}_{2} \mathrm{eq} \mathrm{yr}^{-1}$, respectively, also with good positive correlation, i.e. $\rho=0.81$ $(p<.05)$. For savanna, estimates were $3.15 \pm 0.34 \mathrm{Pg} \mathrm{CO}_{2} \mathrm{eq} \mathrm{yr}^{-1}$ and $2.86 \pm 0.51 \mathrm{Pg} \mathrm{CO}_{2} \mathrm{eq}$ $\mathrm{yr}^{-1}$, respectively, with mild positive correlation, i.e. $\rho=0.46(p<.1)$. For woodland, estimates

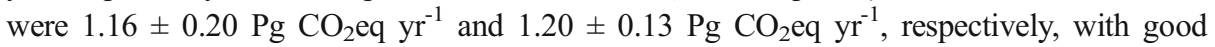
positive correlation, i.e. $\rho=0.82(p<.05)$. Finally for peat fires, only estimates for BruneiDarussalam, Malaysia, and Indonesia were compared, since GFED3 only provides data for these countries. In this geographical region, estimates were $0.37 \pm 0.69 \mathrm{Pg} \mathrm{CO}_{2} \mathrm{eq} \mathrm{yr}^{-1}$ and $0.21 \pm 0.30 \mathrm{Pg} \mathrm{CO}_{2}$ eq $\mathrm{yr}^{-1}$, respectively, with correlation $\rho=0.99(p<.2)$. FAOSTAT peat fires emissions were in general in good agreement with GFED3, although peaks in El Niño years 1997, 2005 and 2008 were higher for GFED3. This implies that the hydrological analysis method employed by GFED3 associates larger peat biomass available for burning in years with pronounced drought, such as those associated with the El Niño phenomena-while the IPCC methods employed by FAOSTAT result in constant values irrespective of soil drought status.

Importantly, it should be noted that FAOSTAT emission estimates for peat fires apply globally, while emissions estimates by GFED only cover three tropical countries: BruneiDarussalam, Malaysia, and Indonesia. Global estimates of peat fires emissions in FAOSTAT, including both tropical and boreal zones, were $1.00 \pm 0.37 \mathrm{Pg} \mathrm{CO}_{2} \mathrm{eq} \mathrm{yr}^{-1}$ over the period

Table 3 Mean, standard deviation, coefficients of variation and t-test statistics of global fire emissions in the 1997-2011 interval, for GFED and FAOSTAT estimates (peat fires limited to Brunei, Malaysia, and Indonesia since GFED only contains these areas)

\begin{tabular}{|c|c|c|c|c|c|c|c|c|c|}
\hline & \multicolumn{3}{|c|}{ GFED $\left(\mathrm{Gg} \mathrm{CO}_{2} \mathrm{eq} \mathrm{yr}^{-1}\right)$} & \multicolumn{3}{|c|}{ FAOSTAT (Gg CO2eq yr-1) } & \multicolumn{3}{|l|}{ t-test } \\
\hline & Mean & stdev & $\mathrm{cv}$ & Mean & stdev & $\mathrm{cV}$ & $\mathrm{t}$ & t crit. 2-tail & $\mathrm{p}$ \\
\hline Deforestation & $1,484,891$ & 619,778 & $42 \%$ & $1,662,906$ & 366,249 & $22 \%$ & 0.96 & 2.07 & 0.35 \\
\hline Forest & $1,022,550$ & 352,411 & $34 \%$ & $1,006,673$ & 166,019 & $16 \%$ & -0.16 & 2.09 & 0.88 \\
\hline Savanna & $3,152,044$ & 339,103 & $11 \%$ & $2,858,242$ & 511,611 & $18 \%$ & -1.85 & 2.05 & 0.07 \\
\hline Woodland & $1,155,256$ & 195,997 & $17 \%$ & $1,202,398$ & 130,350 & $11 \%$ & -0.78 & 2.05 & 0.44 \\
\hline Peatland & 366,846 & 694,043 & $189 \%$ & 238,621 & 317,213 & $133 \%$ & -0.65 & 2.08 & 0.52 \\
\hline TOTAL & $7,181,587$ & $1,369,193$ & $19 \%$ & $6,954,949$ & 852,778 & $11 \%$ & -0.61 & 2.07 & 0.55 \\
\hline
\end{tabular}




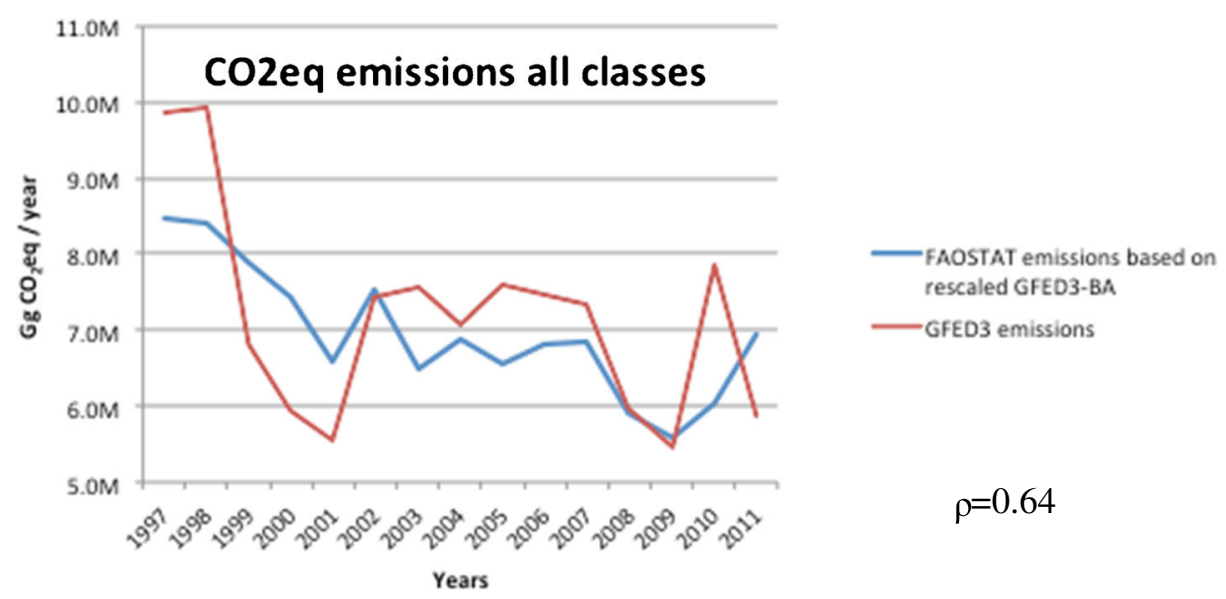

Fig. 1 Comparison of GFED3 and FAOSTAT GHG global total emissions (peat fires limited to Brunei, Malaysia, and Indonesia since GFED only contains these areas)

1997-2001. This results indicate that global emissions from peat fires, once both boreal and tropical fires are included, could be several times larger than those currently estimated by GFED (Fig. 2).

While the above mean emission values by class were found to be not statistically different, differences in CVs between GFED and FAOSTAT were apparent for several emission classes (Table 3). This is related to the inherent higher interannual variability of biomass used in GFED compared to the static values used in FAOSTAT. This mechanism may explain differences in $\mathrm{CV}$ found for forest (34 and $16 \%$, respectively), woodland (17 and $11 \%$, respectively) and deforestation (42 and $22 \%$, respectively), although we did not have access to the underlying biomass data to verify quantitatively this conclusion. For peat fire emission estimates CVs were 189 and $132 \%$, respectively.

The agreement between GFED and FAOSTAT at regional scale was assessed producing geo-spatial maps with grid cell-level analyses of GFED and FAOSTAT data over the period 1997-2011, with respect to single emission classes (Fig. 3). The correlation at pixel level was analysed using the Pearson correlation coefficient, while the difference between the two datasets was assessed using the normalized mean absolute error (NMAE), as suggested by Willmott and Matsuura (2005). The results suggest that the significant consistency between the two methodologies that was found at global level is also maintained at regional scale, given the same burned area datasets used as input by the two methodologies, and despite the use of a complex dynamic biomass predictor in GFED versus the simpler, static FAOSTAT approach described earlier. Relatively lower correlations and higher difference between the data series at pixel level were found in mixed transition areas among different ecosystems, probably due to the different procedures adopted to map the original UMD land cover classes used by the GFED-BA dataset into the classes GFED used to group emissions (Table 2).

Results of the comparisons undertaken herein confirm the original analysis of GFED on the global distribution of GHG emissions from biomass fires (Fig. 4), also summarized in several

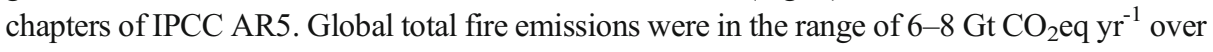
the period 2001-2010. Of this, savanna fires contributed about one-third of total emissions, or

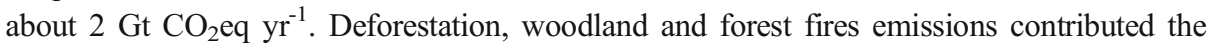
remaining two-thirds. Only about one-third of these emissions constitute anthropogenic 
(a)

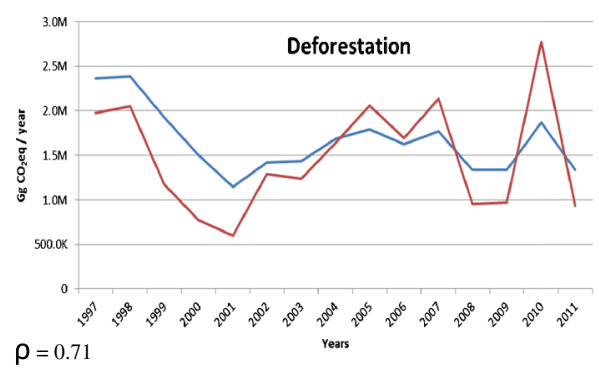

(c)

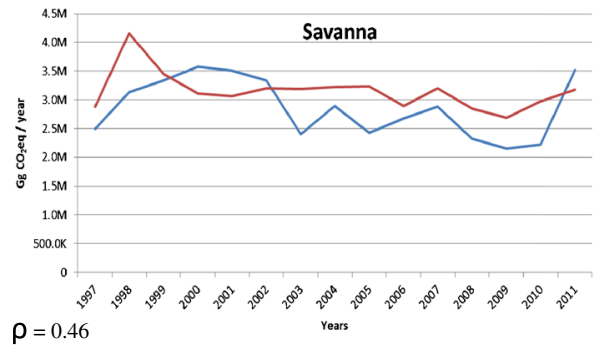

(b)

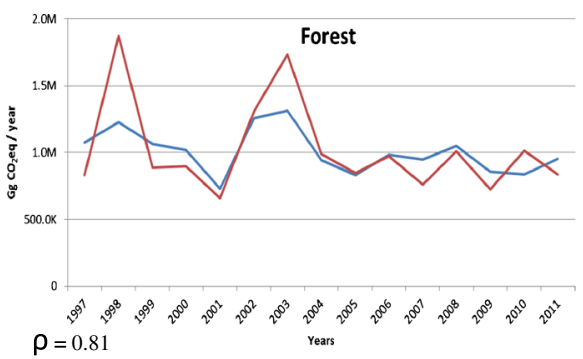

(d)

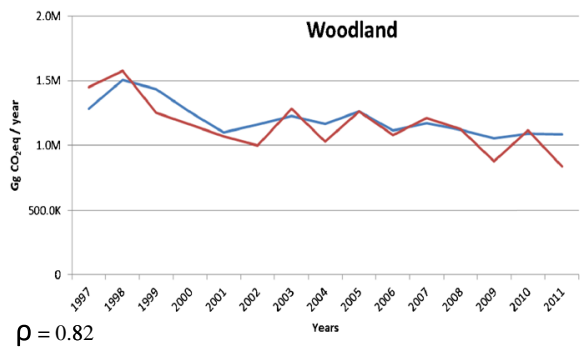

(e)

Peatlands

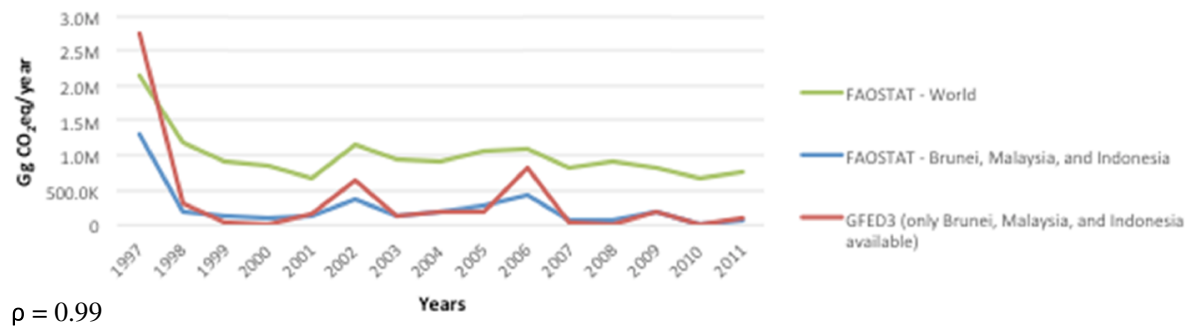

Fig. 2 Comparison of GFED3 and FAOSTAT GHG emissions for each of the indicated fire classes

forcing of the atmosphere and are to be included in national GHG inventories. These include about $1.7 \mathrm{Gt} \mathrm{CO}_{2}$ eq $\mathrm{yr}^{-1}$ (of which $1.5 \mathrm{Gt} \mathrm{CO}_{2}$ eq $\mathrm{yr}^{-1}$ as $\mathrm{CO} 2$ gas, $0.06 \mathrm{Gt} \mathrm{CO}_{2} \mathrm{eq} \mathrm{yr}^{-1}$ as $\mathrm{N}_{2} \mathrm{O}$, and $0.13 \mathrm{Gt} \mathrm{CO}_{2} \mathrm{eq} \mathrm{yr}^{-1}$ as $\mathrm{CH}_{4}$ ) from deforestation fires, and $1 \mathrm{GtCO}_{2} \mathrm{eq} \mathrm{yr}^{-1}$ (of which 0.77

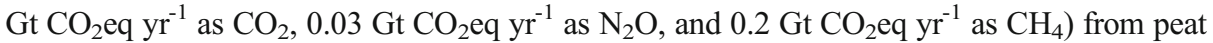
fires, while non- $\mathrm{CO}_{2}$ emissions from savanna and other forest fires amount in total to some 0.3 $\mathrm{Gt} \mathrm{CO}_{2} \mathrm{eq} \mathrm{yr}^{-1}$ (of which $0.15 \mathrm{Gt} \mathrm{CO}_{2} \mathrm{eq} \mathrm{yr}^{-1}$ as $\mathrm{N}_{2} \mathrm{O}$, and $0.15 \mathrm{Gt} \mathrm{CO}_{2} \mathrm{eq} \mathrm{yr}^{-1}$ as $\mathrm{CH}_{4}$ ) (Smith et al. 2014; Tubiello et al. 2014).

\section{Conclusions}

This work investigates differences between GHG emissions from biomass fires, comparing the FAOSTAT estimates, obtained using a default Tier 1 approach according to the IPCC 

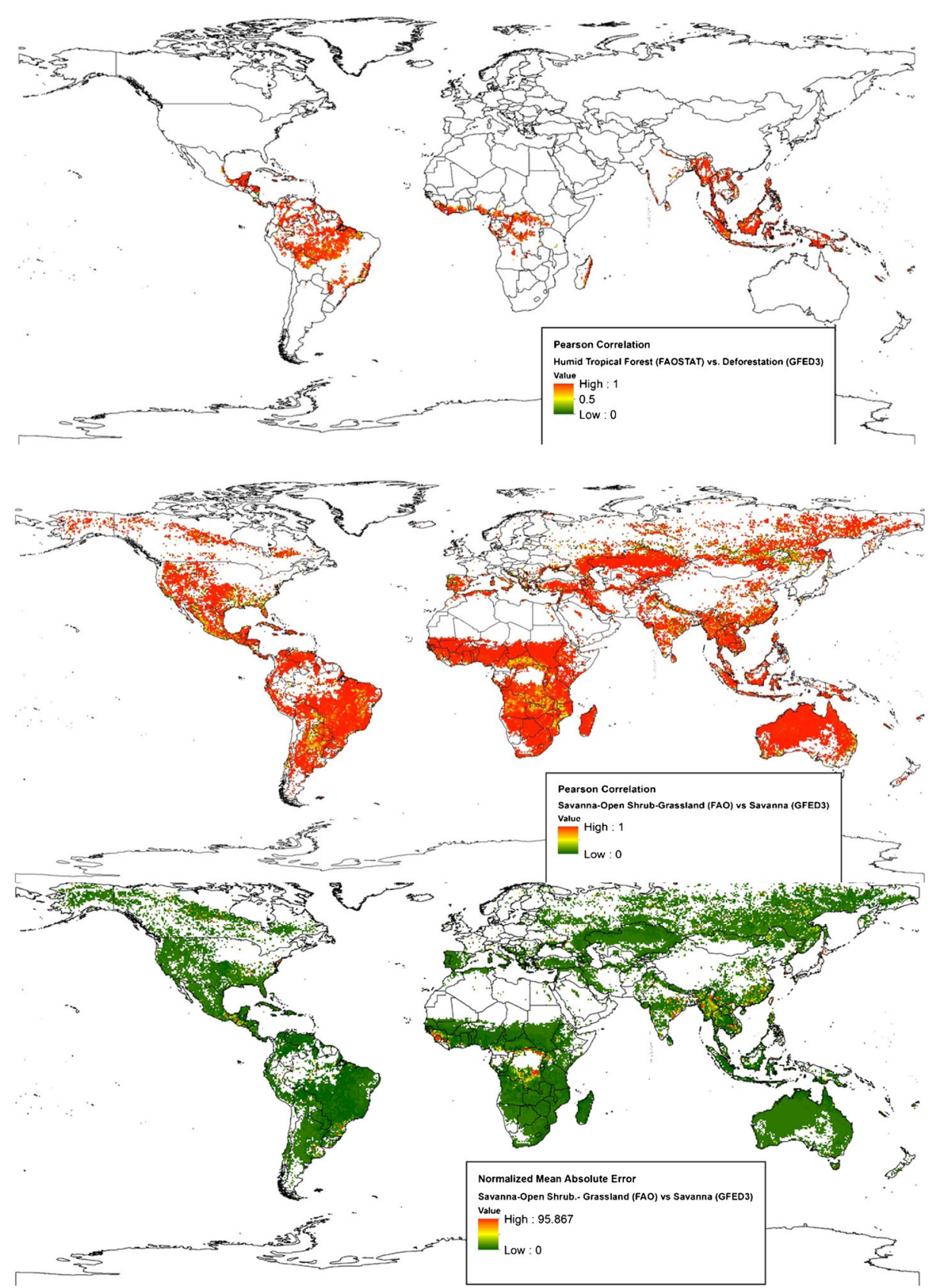

Fig. 3 Maps of the Pearson's correlation coefficient and of the Normalized Mean Absolute Error over the period 1997-2011, between GFED3 and FAOSTAT GHG emission estimates, in the indicated classes: a) Deforestation; b) Forest; c) Savanna; d) Woodland; and e) Peatlands

definition, with the GFED v.3 estimates, obtained through a more complex Tier 3 approach. Results show that the simple Tier 1 approach used in the FAOSTAT Emissions database provides estimates that are not statistically different, at global level, from the Tier 3 GFED 

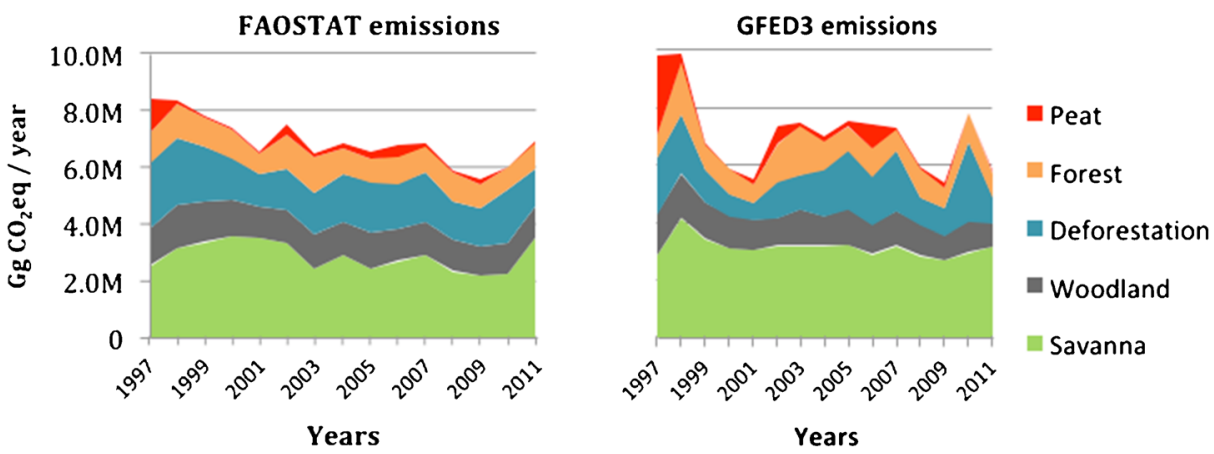

Fig. 4 Breakdown of cumulative global GHG emissions for the indicated fire classes (peat fires limited to Brunei, Malaysia, and Indonesia for consistent comparison with GFED)

estimates. The data estimated with the two methods were shown to have close correspondence with respect to all the land cover classes considered.

This comparison exercise will be repeated with FAOSTAT and GFED4 emission data. Furthermore, in order to improve access to FAOSTAT historical and updated data, we will examine the possibility to employ directly the MCD45A1 burned areas dataset from the NASA MODIS programme instead of GFED processed data.

In conclusion, this study shows that the FAOSTAT Tier 1 approach, using the default widelyapplicable IPCC methodology, produces in general estimates of emissions from biomass burning in line with the results of the widely cited GFED3 database, which are obtained through a complex vegetation growth modelling approach (Tier 3) much more demanding in terms of input data and know-how. This is very important information for inventory compilers from an operational point of view. In many contexts, technical constraints or lack of data limit application and maintenance of higher Tiers methodologies. This is especially the case of developing countries, which starting with 2014 are required to regularly produce estimations of their GHG emissions and submit Biennial Update Report (BUR) to the UNFCCC. Our results show that in these contexts the Tier 1 approach can be considered a reliable option for use in national GHG inventories. FAO makes emissions data available free of charge at www.faostat.fao.org.

Acknowledgments This research was performed under the FAO Monitoring and Assessment of GHG Emissions in Agriculture Project (MAGHG), funded by the Governments of Germany and Norway, GCP/GLO/GER/ 286, GCP/GLO/NOR/325 and GCP/GLO/GER/500. JIH was funded by the Leverhulme Foundation and by EU FP7 through project LUC4C (GA603542).

Open Access This article is distributed under the terms of the Creative Commons Attribution 4.0 International License (http://creativecommons.org/licenses/by/4.0/), which permits unrestricted use, distribution, and reproduction in any medium, provided you give appropriate credit to the original author(s) and the source, provide a link to the Creative Commons license, and indicate if changes were made.

\section{References}

Andreae MO, Merlet P (2001) Emission of trace gases and aerosols from biomass burning. Glob Biogeochem Cycles 15:955-966

Christian TJ, Kleiss B, Yokelson RJ, Holzinger R, Crutzen PJ, Hao WM, Saharjo BH, Ward DE (2003) Comprehensive laboratory measurements of biomass-burning emissions: 1. Emissions from Indonesian, African, and other fuels. J Geophys Res Atmos. doi:10.1029/2003JD003704 
Ciais P, Sabine C, Bala G, et al. (2013) Carbon and other biogeochemical cycles. In: Stocker TF, Qin D, Plattner G-K, et al. (eds) Climate change 2013: the physical science basis. Contribution of Working Group I to the Fifth Assessment Report of the Intergovernmental Panel on Climate Change. Cambridge University Press, Cambridge

FAO/IIASA/ISRIC/ISSCAS/JRC (2012) Harmonized World Soil Database (version 1.2). Food and Agriculture Organization of the United Nations, Rome, Italy, and IIASA, Laxenburg, Austria

Friedl M, Sulla-Menashe D, Tan B, et al. (2010) MODIS collection 5 global land cover: algorithm refinements and characterization of new datasets. Remote Sens Environ 114:168-182

Giglio L, Descloitres J, Justice C, Kaufman Y (2003) An enhanced contextual fire detection algorithm for MODIS. Remote Sens Environ 87:273-282

Giglio L, Loboda T, Roy D, Quayle B, Justice C (2009) An active-fire based burned area mapping algorithm for the MODIS sensor. Remote Sens Environ 113:408-420

Giglio L, Randerson JT, van der Werf GR, et al. (2010) Assessing variability and long-term trends in burned area by merging multiple satellite fire products. Biogeosciences 7:1171-1186

Giglio L, Randerson J, van der Werf G (2013) Analysis of daily, monthly, and annual burned area using the fourth generation Global Fire Emissions Database (GFED4). J Geophys Res Biogeosci 118:1-12

Hansen M, DeFries R, Townshend J, Sohlberg R (2000) Global land cover classification at $1 \mathrm{~km}$ spatial resolution using a classification tree approach. Int J Remote Sens 21:1331-1364

Hayasaka H, Noguchi I, Indra Putra E, Yulianti N, Vadrevu K (2014) Peat-fire-related air pollution in Central Kalimantan, Indonesia. Environ Pollut 195:257-266

IPCC (2006) IPCC Guidelines for National Greenhouse Gas Inventories - Volume 4. Egglestone HS, Buendia L, Miwa K, Ngara T, Tanabe K (Eds), IPCC/TFI

IPCC (2013) Supplement to the 2006 IPCC Guidelines for National Greenhouse Gas Inventories: Wetlands. Hiraishi T, Krug T, Tanabe K, Srivastava N, Baasansuren J, Fukuda M, Troxler TG (Eds), IPCC/TFI

JRC (2010) JRC/IPCC Climate Zones Map. Retrieved 9 6, 2014, from http://eusoils.jrc.ec.europa.eu/projects/ RenewableEnergy/

Olson DM, Dinerstein E, Wikramanayake ED, et al. (2001) Terrestrial ecoregions of the world: a new map of life on Earth. Bioscience 51:933-938

Potter CS, Randerson JT, Field CB, Matson PA, Vitousek PM, Mooney HA, Klooster SA (1993) Terrestrial ecosystem production - a process model based on global satellite and surface data. Glob Biogeochem Cycles 7:811-841

Seiler W, Crutzen PJ (1980) Estimates of gross and net fluxes of carbon between the biosphere and atmosphere from biomass burning. Clim Chang 2:207-247

Smith P, Bustamante M, Ahammad H, et al. (2014) Agriculture, forestry and other land use (AFOLU). In: Edenhofer OR, Pichs-Madruga Y, Sokona E, et al. (eds) Climate change 2014: mitigation of climate change. Contribution of Working Group III to the Fifth Assessment Report of the Intergovernmental Panel on Climate Change. Cambridge University Press, Cambridge

Stocker TF, Qin D, Plattner G-K, et al (2013) Climate change 2013: The physical science basis. Intergovernmental Panel on Climate Change, Working Group I Contribution to the IPCC Fifth Assessment Report (AR5). Cambridge University Press, New York

Stroppiana D, Brivio PA, Grégoire J-M, et al. (2010) Comparison of global inventories of CO emissions from biomass burning derived from remotely sensed data. Atmos Chem Phys 10:12173-12189

Tubiello F, Salvatore M, Rossi S, Ferrara A, Fitton N, Smith P (2013) The FAOSTAT database of greenhouse gas emissions from agriculture. Environ Res Lett. doi:10.1088/1748-9326/8/1/015009

Tubiello FN, Salvatore M, Condor Golec RD, Ferrara AF, Rossi S, Biancalani R, Federici S, Jacobs H, Flammini A (2014) Agriculture, Forestry and Other Land Use Emissions by Sources and Removals by Sinks. ESS Working Paper No. 2. Food and Agriculture Organization of the United Nations, Rome

Tubiello FN, Salvatore M, Alessandro FF, House J, Federici S, Rossi S, Biancalani R, Condor Golec RD, Jacobs H, Flammini A, Prosperi P, Cardenas-Galindo P, Schmidhuber J, Sanz Sanchez MJ, Srivastava N, Smith P (2015) The contribution of agriculture, forestry and other land use activities to global warming, 1990-2012. Glob Ch Biol 21(7): 2655-2660

van der Werf G, Randerson J, Giglio L, et al. (2010) Global fire emissions and the contribution of deforestation, svanna, forest, agricultural, and peat fires (1997-2009). Atmos Chem Phys 10:11707-11735

Willmott CJ, Matsuura K (2005) Advantages of the mean absolute error (MAE) over the root mean square error (RMSE) in assessing average model performance. Clim Res 30:79-82 